\title{
Prevalence of ankylosing spondylitis in males and females in a young middle-aged population of Troms $\varnothing$, northern Norway
}

\author{
J T GRAN, G HUSBY, AND M HORDVIK
}

From the Departments of Rheumatology and Radiology, Institute of Clinical Medicine, University of Troms $\phi$, Troms $\emptyset$, Norway

SUMmaRY In an epidemiological survey in Troms $\varnothing$, northern Norway a prevalence of definite ankylosing spondylitis (AS) of between $1 \cdot 1 \%$ and $1.4 \%$ was found (males: $1.9-2.2 \%$ and females: $0.3-0.6 \%$ ). The ratio of male to female was between 3.9 and 6.1 in favour of the male sex. It was calculated that $6.7 \%$ of the B27 positive individuals had AS, and that $22.5 \%$ of the B27 positive subjects with back pain or stiffness suffered from AS.

Key word: epidemiological survey.

Ankylosing spondylitis (AS) has traditionally been considered a rather rare disease. Autopsy studies from 1932 and $1936^{12}$ suggested a prevalence as low as $0 \cdot 07-0 \cdot 10 \%$. In 1949 West $^{3}$ proposed a prevalence of $0.05 \%$, based on calculations of hospitalised cases of AS in Bristol, England. A marked variation in the geographic distribution of AS was shown by Gofton and coworkers, ${ }^{4}$ whose population studies of male Haida Indians in Canada suggested a prevalence as high as $6 \%$.

Extremely few epidemiological studies of AS have been performed in European populations. ${ }^{5-10}$ The estimated prevalence of AS has varied from $0.08 \%$ to $0.47 \%$, but the different methods employed make reliable comparison between the various studies difficult.

There have also been conflicting opinions with respect to the occurrence of AS in females. ${ }^{3} 1112$ Early studies ${ }^{3}$ regarded AS as extremely rare in women, whereas recent studies of blood donors ${ }^{12}$ have indicated a less pronounced male dominance of the disease. A population study of AS in Hungary ${ }^{6}$ showed a male to female ratio of $5: 1$.

The association between AS and the histocompatibility antigen HLA-B27 is well established. ${ }^{13} 14$ There are, however, conflicting opinions with regard to the frequency of AS in B27 positive

Accepted for publication 20 November 1984

Correspondence to: Dr J T Gran, Lillehammer Sanitetsforenings Revmatismesykehus, 2600 Lillehammer, Norway. persons, ${ }^{12}{ }^{15-17}$ and population studies are clearly needed to obtain reliable information about the absolute risk for $\mathrm{B} 27$ positive persons to have and to get AS.

The aims of the present investigation were to determine the prevalence and the sex ratio of AS in Troms $\varnothing$, northern Norway by surveying a young middle-aged population of both sexes. Furthermore, we wanted to calculate the prevalence of AS in B27 positive persons, based on findings emerging from the same epidemiological survey.

\section{Materials and methods}

GEOGRAPHIC AND POPULATION

CH A R A C T E R IS T I CS

The municipality of Troms $\emptyset$ in northern Norway is located at a latitude of approximately $70^{\circ} \mathrm{N}$. The population comprises three ethnic groups: Lapps $(2 \cdot 3 \%)$, Finns $(4 \cdot 7 \%)$, and Norsemen $(93 \%) .{ }^{18}$ In 1979 there were 45376 inhabitants living in this municipality, which consists mostly of a series of small islands and peninsulas.

The fishing industry has a central position in the occupational life.

EPIDEMIOLOGICAL SURVEY

An epidemiological survey was undertaken in 1979/ 1980 , and all inhabitants (21 329) aged $20-49$ years (females) and 20-54 years (males) were invited to 
participate (female to male ratio $1: 1 \cdot 2$ ). The main purpose of the study was to investigate possible risk factors connected with the development of cardiovascular disorders. ${ }^{19}$ Of the 21329 subjects invited to participate in the study 16621 attended the screening (Table 1). All participants were given a questionnaire and they were instructed to fill in this questionnaire at home and return it by mail. The 14539 participants who returned the questionnaire and answered the questions concerning back problems comprise the subjects of the present analysis (responders). A non-responder was a subject who did not return the questionnaire or returned it without answering the questions about back complaints. Except for a slightly higher age and number of females among responders as compared with non-responders to the questionnaire (Table 2) there were no fundamental differences between responders and non-responders. The questionnaire contained also three questions concerning back pain (Table 3), namely back pain of more than four weeks duration, morning stiffness of the back, and back pain or stiffness relieved by exercise. A positive responder was defined as a person who complained of back pain or back stiffness, or both, (questions 1 and 3, Table 3) on the questionnaire. A negative responder was a subject who answered negatively to both questions about back complaints.

\section{SAMPLING PROCESSES OF PERSONS}

WITH BACK PAIN

Table 2 shows that 2907 subjects (female to male ratio $1: 1.2$ ) of the 14539 responders complained of pain or stiffness in the back. Of those 2907 positive responders a random sample of 806 subjects $(28 \%)$ was drawn (female to male ratio $1: 1 \cdot 3$ ) by offering clinical examination to those who were born on 12 randomly selected days in a month. There were no differences between the 806 invited subjects and the remaining 2101 positive responders with respect to mean age, sex distribution, and number of positive answers to the questions of back pain (data not shown). Of the 806 persons invited 449 (56\%) turned up for examination (female to male ratio of 1:1.4). The completion rate was thus slightly, but non-significantly, higher for males as compared with females, but otherwise there were no other fundamental differences between these two groups.

\section{DIAGNOSTIC CRITERIA}

The New York criteria ${ }^{20}$ for definite AS were applied, and only patients with definite $x$-ray changes in the sacroiliac joints were accepted as definite AS. Patients with juvenile onset AS (15 years or younger) and patients with accompanying

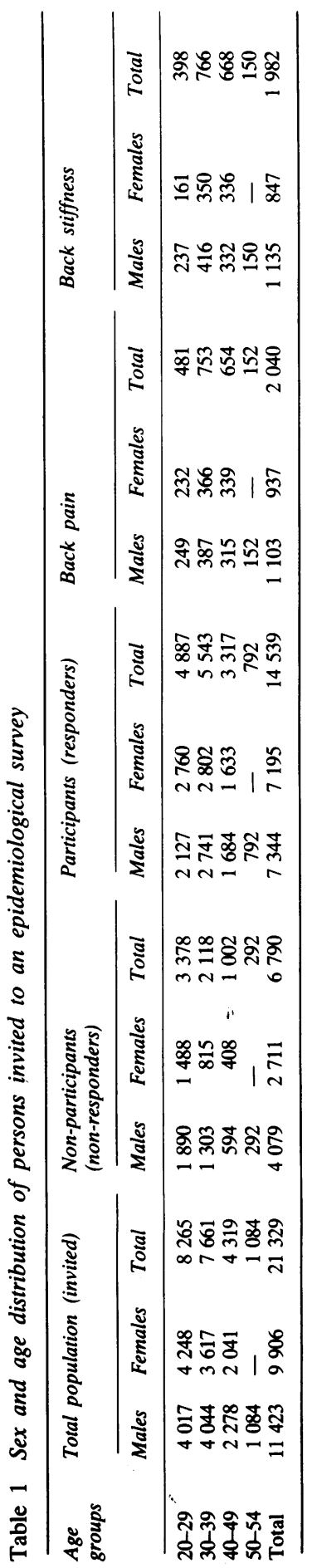


Table 2 Mean age, sex ratio, and frequency of registration by the local hospital in various epidemiological groups

\begin{tabular}{|c|c|c|c|c|c|c|c|c|c|}
\hline \multirow[t]{2}{*}{ Category } & \multirow[t]{2}{*}{ No. } & \multirow[t]{2}{*}{$\begin{array}{l}\text { Mean age } \\
\text { (years) }\end{array}$} & \multirow[t]{2}{*}{$\begin{array}{l}\text { Sex ratio } \\
\text { males:females }\end{array}$} & \multicolumn{2}{|c|}{$\begin{array}{l}\text { Registered as AS } \\
\text { (specific sickness I) }\end{array}$} & \multicolumn{2}{|c|}{$\begin{array}{l}\text { Registered with any } \\
\text { disorder of the back } \\
\text { (specific sickness II) }\end{array}$} & \multicolumn{2}{|c|}{$\begin{array}{l}\text { Attended the } \\
\text { local hospital } \\
\text { (general sickness) }\end{array}$} \\
\hline & & & & No. & $\%$ & No. & $\%$ & No. & $\%$ \\
\hline $\begin{array}{l}\text { Positive } \\
\text { responders } \\
\text { Negative }\end{array}$ & 2907 & $36 \cdot 5$ & $1 \cdot 2: 1$ & 12 & 0.4 & 68 & $2 \cdot 3$ & 762 & $26 \cdot 2$ \\
\hline responders & 11632 & $34 \cdot 0$ & $1 \cdot 0: 1$ & 0 & 0.0 & 38 & 0.3 & 1986 & $17 \cdot 1$ \\
\hline $\begin{array}{l}\text { Non-responders } \\
\text { Positive and } \\
\text { negative }\end{array}$ & 6970 & $31 \cdot 7$ & $1 \cdot 5: 1$ & 5 & $0 \cdot 1$ & 45 & $0 \cdot 7$ & 1136 & $16 \cdot 3$ \\
\hline responders & 14539 & $34 \cdot 3$ & $1 \cdot 0: 1$ & 12 & $0 \cdot 1$ & 106 & $0 \cdot 7$ & 2748 & $18 \cdot 9$ \\
\hline Total invited & 21329 & $33 \cdot 5$ & $1 \cdot 2: 1$ & 17 & $0 \cdot 1$ & 151 & $0 \cdot 7$ & 3884 & $18 \cdot 2$ \\
\hline
\end{tabular}

Table 3 Questions used in the questionnaire concerning back pain

1. Have you during the last 12 months been troubled by back pain of more than four weeks' duration?

2. If yes, does the back pain improve with exercise?

3. Have you had morning stiffness in the back of more than 30 minutes duration?

psoriasis or inflammatory bowel disease were excluded. Accordingly, one person with juvenile-onset AS was excluded.

\section{ROENTGENOLOGICAL GRADING SYSTEM}

The grading system of Dale ${ }^{21}$ for arthritic changes of the sacroiliac joints was used (Table 4). In this system grade 0 refers to normal findings, grade I suspicious changes, grade IIa definite unilateral and grade IIb definite bilateral changes, grades III and IV severe arthritic changes, and grade $\mathrm{V}$ total bony ankylosis of the sacroiliac joints. Grades II-V thus represent definite arthritic changes, and consequently correspond to the New York criteria grades III-IV.

\section{ROENTGENOLOGICAL EXAMINATION}

Standard $x$-rays of the sacroiliac joints (anteriorposterior and posterior-anterior views) and of the dorsolumbar junction (anterior-posterior and lateral views) were preferred. All persons who underwent clinical examination were requested to attend for radiological examination, except those who had available and appropriate films taken not more than two years before the examination ( 25 subjects). In this way, $x$-rays of 375 of the $\mathbf{4 4 9}$ persons examined clinically were accomplished (83.5\%). The 74 persons $(16 \cdot 5 \%)$ who did not come for $x$-ray examination were compared with the 375 persons with available films for a number of characteristics (Table $5)$. No statistically significant differences between
Table 4 Radiological grading of sacroiliitis*

\section{Grade Arthritic condition}

$0 \quad$ Normal conditions. With normal widths and sharp margins of the joints. A slight sclerosis of the ileum side of the joint may be present

I Suspicious changes. The radiologist is uncertain whether there are changes described under grade II

II Definite early changes. Pseudo-widening of the joint space and localised areas, or both, with erosions. Sclerosis of the bone usually on both sides of the joint space. Blurring of the joint margins often present. IIa. Unilateral changes; IIb. bilateral changes

III Severe destructive changes. The erosions and often the pseudo-widening at least in one joint are more marked than in grade II. The arthritic changes are always bilateral. Small bony bridges may be present

IV Regressive changes. Bilateral arthritic changes as described under grade III, but in addition signs of narrowing of the joint space, often with bony bridges in one or both sacroiliac joints. Some regress of the sclerosis in the neighbourhood of the joint

V Terminal changes. Pronounced signs of bony ankylosis in both sacroiliac joints. Regress of the sclerosis in the neighbourhood of the joints

${ }^{*}$ According to Dale. ${ }^{21}$

these two groups were found with respect to spinal mobility, mean duration of morning stiffness, mean age, sex ratio, and duration of back pain.

The 375 films were read by a radiologist who was unaware of the clinical status of the patients. All films defined as grade I (suspicious changes) and grades II-V (definite changes) were then read blindly by a second radiologist. These films were mixed with $\mathbf{4 5}$ other randomly selected films (i.e. a total of 96 films) defined as normal ones (grade 0 ) by the first observer. Table 6 shows that a full agreement between the two observers was obtained in 74 of the $x$-rays $(77 \cdot 1 \%)$, while in eight films $(8.3 \%)$ the two observers differed in the degree of 
Table 5 A comparison of persons who were x-rayed after clinical examination and those who did not turn up for $\frac{}{6}$ radiological examination

\begin{tabular}{|c|c|c|c|c|c|}
\hline Variable & $\begin{array}{l}\text { Examined with } \\
x \text {-ray }(n=375)\end{array}$ & $\begin{array}{l}\text { Examined without } \\
x \text {-ray }(n=74)\end{array}$ & $t$ & $d f$ & $p$ \\
\hline Mean age (years) & $38 \cdot 4$ & $37 \cdot 5$ & 0.85 & 447 & NS \\
\hline Sex (male to female ratio) & $1 \cdot 1$ & $1 \cdot 0$ & 0.82 & 447 & NS \\
\hline \multicolumn{6}{|l|}{ Duration of back pain of } \\
\hline three months or more $(\%)$ & $50 \cdot 4$ & $51 \cdot 6$ & 0.59 & 429 & NS \\
\hline Duration of back pain (years) & $15 \cdot 9$ & $14 \cdot 8$ & 0.95 & 439 & NS \\
\hline Morning stiffness (hours) & 0.7 & 0.6 & 0.53 & 432 & NS \\
\hline Mean Schober's test (cm) & $4 \cdot 4$ & $4 \cdot 3$ & 0.60 & 443 & NS \\
\hline \multicolumn{6}{|l|}{ Mean spondylometry flexion } \\
\hline (degrees) & $52 \cdot 2$ & $52 \cdot 8$ & 0.45 & 438 & NS \\
\hline \multicolumn{6}{|l|}{ Mean spondylometry } \\
\hline extension (degrees) & $24 \cdot 4$ & $24 \cdot 7$ & $0 \cdot 30$ & 437 & - NS \\
\hline
\end{tabular}

NS $=$ Not significant. $\mathrm{df}=$ Degree of freedom.

Table 6 Interobserver variance of $\mathrm{x}$-ray changes in the sacroiliac joints

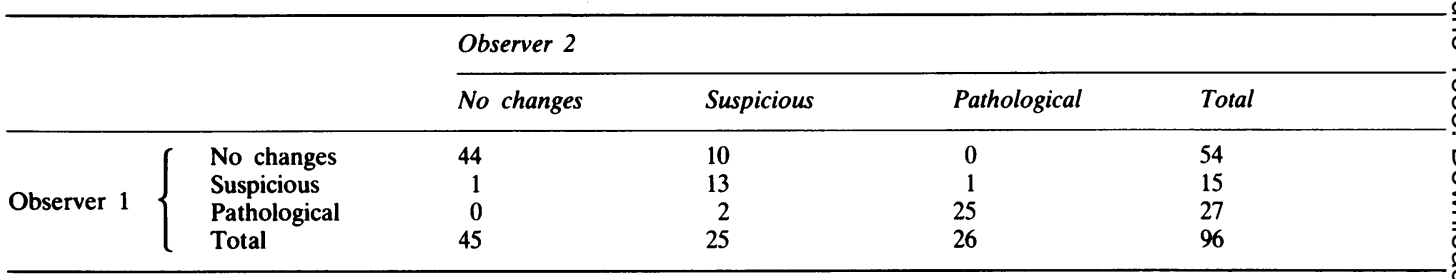

abnormality but both interpreted these eight films as showing definite changes. Eleven $x$-rays $(11.5 \%)$ were interpreted as showing suspicious changes by one observer, but the other radiologist regarded them as normal. Thus in $96.9 \%$ of the films the two observers agreed on whether or not definite arthritic changes were present. Three films were, however, considered to show definite changes by one radiologist, while the other regarded the changes as suspicious only. A third radiologist then examined these films without knowing the conclusions of the former two observers. His opinion of these three films was accepted as final, and all three films were found to exhibit definite arthritic changes.

TYPING FOR HLA-B2T

The typing of HLA-B27 was performed according to standard techniques previously described. ${ }^{22}$ It was attempted to tissue type all 449 patients either at the clinical examination or later at the roentgenological examination, and it was performed successfully in only 380 patients $(84 \cdot 6 \%)$. There were no statistically significant differences between those typed and those who were not tissue typed with regard to sex ratio and severity of back pain (Table 7). Mean age was higher and mean duration of back pain longer? among those typed for B27 compared with subjectso who were not tissue typed.

CLINICAL EXAMINATION

The clinical examination was done without knowledge of the results of the $x$-ray examination or B27 typing, as these investigations postdated the clinical examination. Schober's test for lumbar mobility was윽 performed according to the method described by $D$ Macrae and Wright, ${ }^{2.3}$ and measurements less than $4.5 \mathrm{~cm}$ were defined as pathological. Measurements of total spinal mobility (except for the cervical ${ }^{\circ}$ spine) were determined with a spondylometer, ${ }^{24}$ and 0 $40^{\circ}$ flexion and $20^{\circ}$ extension were used as lower $\omega$ limits of normal mobility. Measurements of chesto expansion also followed standard procedures, ${ }^{25}$ witho less than $6 \mathrm{~cm}$ defined as restricted mobility. The $\bar{\complement}$ posture, the lumbar lordosis, and lateral lumbar ${ }^{?}$ mobility were all judged individually by each examiner. There were four examiners, three specially trained last-year medical students and one rheuma- $\stackrel{\mathbb{Q}}{\not}$ tologist. Examination of peripheral joints was done only for those patients who had complaints (pain oro stiffness) in such joints. 
Table 7 Some characteristics of subjects volunteering for tissue typing and those who did not turn up

\begin{tabular}{|c|c|c|c|c|c|c|c|c|c|c|}
\hline \multirow[t]{2}{*}{ Variable } & \multicolumn{5}{|c|}{ Examined clinically $(n=449)$} & \multicolumn{5}{|c|}{ Examined clinically and $\mathrm{x}$-rayed $(n=375)$} \\
\hline & $\begin{array}{l}\text { Tissue } \\
\text { typed }\end{array}$ & $\begin{array}{l}\text { Not } \\
\text { typed }\end{array}$ & $t$ & $d f$ & $p$ & Typed & $\begin{array}{l}\text { Not } \\
\text { typed }\end{array}$ & $t$ & $d f$ & $p$ \\
\hline Mean age (years) & $38 \cdot 8$ & $34 \cdot 4$ & $3 \cdot 6$ & 447 & $<0 \cdot 01$ & $39 \cdot 0$ & $33 \cdot 7$ & $3 \cdot 8$ & 373 & $<0.01$ \\
\hline $\begin{array}{l}\text { Reporting back pain of } \\
\text { three months or } \\
\text { more }(\%)\end{array}$ & $50 \cdot 5$ & $51 \cdot 3$ & 0.3 & 429 & $>0.5$ & $50 \cdot 1$ & $52 \cdot 8$ & 0.9 & 358 & $>0.2$ \\
\hline $\begin{array}{l}\text { Duration of back } \\
\text { pain (years) }\end{array}$ & $16 \cdot 0$ & $13 \cdot 1$ & $2 \cdot 2$ & 439 & $<0.05$ & $16 \cdot 3$ & $12 \cdot 1$ & 2.7 & 366 & $<0.01$ \\
\hline Morning stiffness (hours) & 0.7 & 0.5 & $1 \cdot 1$ & 432 & $>0.2$ & 0.7 & $0 \cdot 6$ & 0.7 & 361 & $>0.2$ \\
\hline $\begin{array}{l}\text { Mean Schober's test }(\mathrm{cm}) \\
\text { Mean spondylometry }\end{array}$ & $4 \cdot 4$ & $4 \cdot 3$ & 0.7 & 443 & $>0.2$ & $4 \cdot 4$ & $4 \cdot 5$ & 0.5 & 369 & $>0 \cdot 5$ \\
\hline $\begin{array}{l}\text { flexion (degrees) } \\
\text { Mean spondylometry }\end{array}$ & $52 \cdot 1$ & $53 \cdot 6$ & $1 \cdot 1$ & 438 & $>0 \cdot 2$ & $51 \cdot 9$ & $55 \cdot 3$ & $2 \cdot 2$ & 366 & $<0 \cdot 05$ \\
\hline extension (degrees) & $24 \cdot 5$ & $24 \cdot 2$ & 0.2 & 437 & $>0.5$ & $24 \cdot 3$ & $25 \cdot 1$ & 0.6 & 365 & $>0.5$ \\
\hline Male:female ratio & $1 \cdot 1$ & $1 \cdot 0$ & $1 \cdot 0$ & 447 & $>0.2$ & $1 \cdot 1$ & $1 \cdot 0$ & 0.7 & 373 & $>0.2$ \\
\hline
\end{tabular}

$\mathrm{df}=$ Degrees of freedom

\section{CONTROL MATERIAL}

Clinical examination of persons who did not report back pain on the questionnaire (negative responders) was not done. A control group was established of all persons registered by the local and regional hospital (Regional Hospital of Troms $\varnothing$ ) under all diagnoses in the ICD system (International Classification of Diseases) except partus (general sickness). The distribution of these subjects among positive responders, negative responders, and nonresponders was investigated.

\section{ST A T IS T I CS}

The $\chi^{2}$ test and Student's $t$ test were used, and a $\mathrm{p}$ value of less than 0.05 was accepted as significant. The tests were done as two-tailed tests, and the alpha levels were not adjusted for the number of hypotheses tested for.

\section{Results}

CONTROL GROUP

There were no statistically significant differences in general sickness between positive responders, negative responders, and non-responders, but a statistically higher frequency of back diagnosis was found among positive responders $(2 \cdot 3 \%)$ as compared with negative responders $(0 \cdot 3 \%) \quad\left(\chi^{2}=130 \cdot 2, \quad \mathrm{df}=1\right.$, $\mathrm{p}<0.001$ ) (Table 2). Twelve of the patients with definite AS registered by the hospital were found among positive responders $(0.4 \%)$, in contrast to none in the group of negative responders (Table 2) $\left(\chi^{2}=48 \cdot 0, \mathrm{df}=1, \mathrm{p}<0 \cdot 001\right)$. A lower mean age and a stronger male dominance were noted among nonresponders as compared with responders.
PREVALENCE OF AS

Of the 375 persons who were $x$-rayed 27 persons were found to satisfy the New York criteria for definite AS. ${ }^{20}$ Twenty-six of these 27 persons had definite bilateral changes of the sacroiliac joints characteristic of AS. One patient had unilateral definite changes (the other joint regarded as suspicious) and restricted mobility of the lumbar spine in all three planes. If the $375 x$-rayed persons were regarded as a random sample of the total number of 2907 persons reporting back pain, a total of 209 subjects in the latter group should have AS. A prevalence of $1.4 \%$ was calculated provided all negative responders (not reporting back pain) did not suffer from AS (Table 8). However, more AS patients (22 patients) derived from the responders who gave two positive answers concerning back complaints than those with one positive answer (five patients). Adjustment for this difference revealed a prevalence of AS of $1 \cdot 1 \%$. The prevalence of AS in this population was thus somewhere between $1 \cdot 1 \%$ and $1 \cdot 4 \%$.

SEX RATIO OF AS

Among the 27 persons with AS 22 were males and five were females. There were 1611 males and 1296 females reporting back complaints in the survey, and 216 of the males and 159 of the females were examined and $x$-rayed. The prevalence of AS was consequently estimated to be $2 \cdot 2 \%$ for the males and $0 \cdot 6 \%$ for females. Taking into account the number of males and females derived from the different back pain categories (two positive answers versus one positive answer) a prevalence of $1.9 \%$ for males and $0.3 \%$ for females was calculated. The 


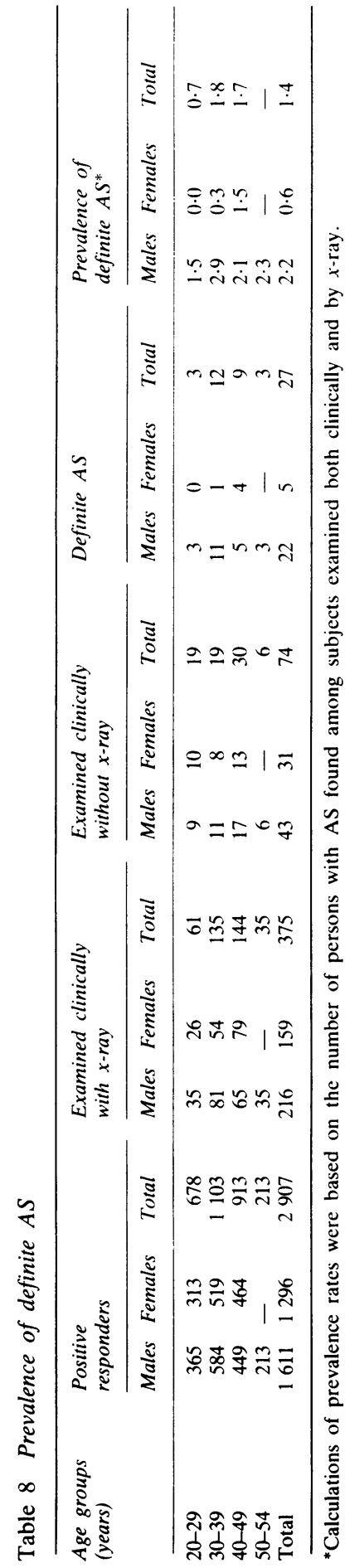

former calculation yielded a sex ratio of 3.9:1, the latter a ratio of $6 \cdot 1: 1$, both in favour of males. $\vec{F}$

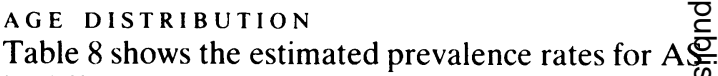
in different age groups. When taking the back pair categories into account it was found that the prevalence rate increased with advancing age, the maximum prevalence $1.7 \%$, being found in the ag 5 group of 50-54 years. A prevalence increasing withadvancing age was not so pronounced when thisu possible sampling error was not considered (Tableg 8).

\section{FREQUENCY OF H LA - B 27}

Twenty out of 22 male AS patients $(91 \%)$ and thre of four $(75 \%)$ female patients carried HLA-B27, the overall frequency of $\mathrm{B} 27$ being $88.5 \%$.

FREQUENCY OF AS IN PERSONS CARRYIN孚 H L A - B 27

The frequency of HLA-B27 in the general popula $\overrightarrow{0}$ tion of blood donors of Troms $\emptyset$ is $15.9 \%,{ }^{22}$ and was estimated that $6.7 \%$ of all B27 positive persone in the actual age groups had AS, the figures bein $1.5 \%$ for females and $11.1 \%$ for males (Table 9). 0 \% the B27 negative persons, $0.2 \%(0.1 \%$ of females and $0.2 \%$ of the males) had AS (Table 9). Amonis the $338 x$-rayed persons typed for B27 $102(30 \cdot 2 \%$ carried HLA-B27. Twenty-three of the 102 B2 $\bar{\Phi}$ positive persons had AS, hence the frequency of $A \Im$ in B27 positive persons with back pain was $22.5 \%$ the figures for males and females being $31.3 \%$ and $7.9 \%$ respectively. Four out of 236 B27 negativ persons with back pain $(1.3 \%)$ had AS (Table 9$) \circ$

\section{Discussion}

In the present study all persons who reported no back pain or stiffness (negative responders) were considered not to have AS. It was beyond ous capacity to examine this group further, but analyse of the control material did not reveal a single hospitalised case of AS among these persons. Outo estimate may thus be quite valid, though it has beet shown by us ${ }^{26}$ and by others ${ }^{27}$ that most AS patients detected in epidemiological surveys are not registered by the regional or local hospital. We do find it unlikely, however, that many cases of definite $A \$$ were hidden among the persons denying pain ofo stiffness of the back.

Owing to differences in age and sex distributio between non-responders and responders, an exक्ष amination of a random sample of non-responder尺े may have been warranted. Unfortunately it was not possible to include such a control group, but the 
Table 9 Prevalence (\%) of definite AS in persons with and without HLA-B27

\begin{tabular}{|c|c|c|c|c|c|c|}
\hline \multirow[t]{2}{*}{$H L A-B 27$} & \multicolumn{3}{|c|}{ Total population } & \multicolumn{3}{|c|}{ Persons with back pain } \\
\hline & Males & Females & Total & Males & Females & Total \\
\hline Positive & $11 \cdot 1$ & $1 \cdot 5$ & $6 \cdot 7$ & $31 \cdot 3$ & 7.9 & $22 \cdot 5$ \\
\hline Negative & $0 \cdot 2$ & $0 \cdot 1$ & $0 \cdot 2$ & 1.6 & 0.9 & $1 \cdot 3$ \\
\hline Total & 1.9 & $0 \cdot 3$ & $1 \cdot 1$ & $11 \cdot 6$ & $2 \cdot 7$ & $7 \cdot 7$ \\
\hline
\end{tabular}

similar frequencies of hospitalisation due to AS and other back disorders in these two groups may indicate that the occurrence of AS among the 14539 responders was representative of the total population.

It was estimated that 209 cases of AS occurred among the 14539 responders, and that of these 209 persons only $12(6 \%)$ were known from the hospital records. Accordingly it could be concluded that of the total pool of AS in the Trosmø population $94 \%$ of patients were not sufficiently ill to be seen at the hospital. Evidently this apparently very high nosocomial threshold for AS may have other explanations. One possible explanation is that some of the cases of AS admitted to the regional hospital of Troms $\varnothing$ were seen at the outpatient clinic only and were consequently not registered in the hospital files. Furthermore the Department of Rheumatology was started only in 1978, and many cases of AS might not have been referred to the department by the time of the epidemiological survey. On the other hand, in the study of Calin and coworkers ${ }^{27}$ only $6.3 \%$ of the patients with AS in an industrial complex were aware of the diagnosis, a figure strikingly similar to ours.

Clinical examination was performed by four observers, three of whom were last-year medical students, and all four examiners were aware of the fact that every respondent examined was a back complainer'. To establish a diagnosis of definite AS clinical evidence of the disease was required to support the radiological findings in only one out of 27 cases detected in the present survey. It was therefore unlikely that the clinical examination introduced observer biases which influenced the estimation of the prevalence of AS.

Furthermore it could be argued that the persons who did not show up for roentgenological examination were those with less severe back pain. When comparing these persons with those $x$-rayed, however, no convincing differences between the two groups emerged with respect to severity of back pain or other characteristics. Thus the calculated prevalence of $1 \cdot 1-1 \cdot 4 \%$ of definite AS may be quite close to the true prevalence of AS in our population.
The three questions of back pain used on the questionnaire were certainly not sufficiently specific to differentiate between inflammatory disorders and other more or less defined diseases of the back. Duration of back pain of more than three months instead of four weeks and an additional question about insidious onset of such pain would possibly have increased the specificity for AS, as suggested by Calin and coworkers. ${ }^{27}$ Thus our screening questions for AS presumably had a low specificity, as indicated by the low number of AS patients among those examined for back pain, but as a higher sensitivity would be expected by employing our questions, we do not believe that many cases of AS were missed.

Interpretation of $x$-rays of the sacroiliac joints is difficult and may be hampered by both inter- and intraobserver variation. ${ }^{28-30}$ An observer variation study was conducted and indicated that the grading system employed ${ }^{21}$ was satisfactory with respect to differentiation between definite arthritic changes and normal findings. We feel that the interpretation of sacroiliac $x$-rays did not influence our estimate of the prevalence of AS to a great extent. It is, however, generally accepted that clinical signs and symptoms of AS do always precede the development of radiological sacroiliitis. Consequently the total reliance of the New York criteria ${ }^{20}$ on radiological changes for the diagnosis of AS is by no means perfectly satisfactory. In the present study some persons with $x$-rays interpreted as showing suspected arthritic changes only may later go on to develop definite radiological sacroiliitis. Thus despite suffering from AS, the New York criteria ${ }^{20}$ owing to the absence of crucial radiological features, failed to include these patients. On the other hand because of inherent difficulties in the interpretation of radiological changes of the sacroiliac joints, some of the less severe cases of radiological sacroiliitis in the present survey might have been defined as suspected sacroiliitis by other groups of investigators. Consequently a need to establish diagnostic criteria of AS independent of definite $x$-ray findings seems highly warranted. Furthermore in order to include all true cases of AS an accurate estimation of 
its prevalence according to the New York criteria ${ }^{20}$ should be based primarily on longitudinal surveys. This will probably also reduce the errors inevitably introduced by variations in the interpretation of radiological sacroiliitis. A re-examination of the persons with back pain presently studied is therefore in progress. The purpose of this follow up is both to determine the prevalence of AS more accurately and also to establish clinical diagnostic criteria for this rheumatic disorder.

The prevalence of AS of $1 \cdot 1-1.4 \%$ was approximately three times as high as the prevalence determined by Gömör and coworkers ${ }^{6}$ in Hungary. The difference cannot be explained satisfactorily by the somewhat higher frequency of the AS susceptibility gene HLA-B27 in northern Norway $(15.9 \%)^{22}$ than that found in the general population of Hungary $(12 \cdot 8 \%){ }^{6}$ The two studies differed in their ways of inviting persons with back pain for $x$-ray examination. In the present study all examined persons were invited to a roentgenological examination regardless of their clinical status, whereas in the Hungarian study ${ }^{6}$ only in patients where AS was suspected on clinical grounds were appropriate radiographs taken. In our experience it was not possible to differentiate suspected AS and definite AS solely by clinical examination, hence some cases of AS may by a selection bias have been missed in the Hungarian study.

Gofton and coworkers ${ }^{4}$ found a prevalence of AS as high as $6 \cdot 1 \%$ among male Haida Indians. If only persons with grade III and grade IV arthritis of the sacroiliac joints according to the New York criteria ${ }^{20}$ were considered, a prevalence of $4.3 \%$ was calculated. This estimate is higher than the male prevalence of $1 \cdot 9-2 \cdot 2 \%$ calculated in the present study. The difference is best explained by the higher prevalence of B27 (50\%) among Haida Indians as compared with the prevalence of $15.9 \%$ in northern Norway. ${ }^{22}$ The results are, however, to some extent comparable, as $8.6 \%$ of the B27 positive male Haidas had AS as compared with $11.1 \%$ of the B27 positive males in northern Norway. As far as we could calculate this difference $(11.1 \% v 8.6 \%)$ was not statistically significant $\left(\chi^{2}=0.7 \mathrm{df}=1, p>0.5\right)$.

Another Norwegian study ${ }^{7}$ showed a prevalence of AS in males living in the southern part of the country of $0 \cdot 17-0.31 \%$. The study, however, was not comparable with our survey, as it was based on hospital records, and moreover, defined diagnostic criteria were not employed. Furthermore the prevalence of B27 in the general population of southern Norway $(8-10 \%)$ is significantly lower than that of $15.9 \%$ in northern Norway. ${ }^{22}$

A study by Kuberski and coworkers ${ }^{31}$ of the prevalence of AS in Navajo and Hopi Indians based on hospital records showed a prevalence of definite AS of $0 \cdot 129 \%$. However, as we previously noted ${ }^{26} \Rightarrow$ and as clearly shown by Calin and coworkers ${ }^{27}$ the $\stackrel{\vec{P}}{+}$ number of hospitalised patients with AS is rathero low compared with the actual number of AS patients present in the population. Thus different prevalence? rates obtained through hospital based studies and® population surveys of AS may not reflect a realळ difference of the prevalence of AS in the general population.

The male dominance of AS was slightly less pronounced in this survey $(3.9-6 \cdot 1: 1)$ than in most previous estimates, ${ }^{11} 123233$ which agreed with recent proposals that AS is not a rare disease in the female sex. ${ }^{3}$ On the other hand the recent proposals $\dot{\sigma}$ of an equal sex distribution of AS emerging throughis studies of blood donors, ${ }^{12}$ could not be supported byc our results.

The prevalence of B27 among our AS patientswas rather low $(89 \%)$ as compared with othere studies $(92-100 \%) .{ }^{13} 34{ }^{35}$ This can be explained by the low number of AS patients found, as the prevalence of $89 \%$ was not statistically significantlyo o different from the prevalence of B27 among our hospitalised patients, i.e., $95 \%{ }^{26}$

Different studies of blood donors have estimated the risk of having AS for a B27 positive carrier too vary from $0.3 \%$ to $25 \% .^{12151636}$ The presento epidemiological study concluded that there is a risk of $6.7 \%$ for a B27 positive person to have AS. The $\overrightarrow{\overrightarrow{0}}$ pronounced discrepancies can be explained by the 3 different selection criteria used in these studies. Interestingly, the high risk of $20 \%$ calculated by Calin and Fries ${ }^{12}$ would yield a prevalence of definite AS of $1-1.5 \%$ in the general population, while the $0 \cdot 3-3 \%$ chance estimated by Christiansen and coworkers ${ }^{16}$ would give a prevalence of less than $0.04 \%$. Since the prevalence of AS tends roughly to 3 correlate with the prevalence of B27 in the generalo population, it is inappropriate to say that the prevalence of AS observed in northern Norwayo (frequency of $\mathrm{B} 27=15.9 \%$ ) is similar to that reported by Calin and Fries ${ }^{12}$ (frequency of B27 $=6-\sigma$ $8 \%$ ). Apart from the difference in estimated risks in N B27 positives it should be noted that the prevalencen rate of AS suggested by Calin and Fries ${ }^{12}$ was based $\omega$ on a $6 \%$ prevalence of AS among their B27 negative subjects, which is an extremely high prevalencec when compared with the risk of $0.2 \%$ in $\mathrm{B} 27$ negatives? calculated in the present population survey.

Because of its low specificity, testing for HLA-O응 B27 has been regarded as of little value in the diagnosis of $\mathrm{AS}^{37}{ }^{38}$ To a certain extent we agree with these conclusions, as only $6.7 \%$ of B27 positive persons in our population had AS. However, in persons with low back pain a higher risk $(22.5 \%)$ 
was calculated, indicating a higher diagnostic value of the B27 test than previously suggested. ${ }^{37} 38$

To conclude, the survey indicated that the prevalence of definite AS is much higher than previously thought and that the male preponderance of AS, though indeed present, appears less pronounced than generally accepted.

The valuable advice of Professors Knut Westlund and Dag Thelle, Institute of Community Medicine, University of Troms $ø$, Norway is greatly acknowledged. We also thank Ms Gretha Larssen and Ms Anita Skoge Hoel for typing the manuscript.

This work was supported by the Norwegian Research Council for Science and Humanities, the Norwegian Women's Health Association, and the Norwegian Rheumatism Council.

\section{References}

1 Clausen F, Kober E. Über die Veranlagung zu Bechterewscher Krankheit und ihre Wesen. Z Menschel Vererb Konstit-Lehre 1939; 22: 268-303.

2 Schmorl G, Junghans H. Die gesunde und Kranke Wirbelsäule, Leipzig 1932. Ergänzungsband 43. Vortschritte auf dem Gebiete der Röntgenstrahle.

3 West H F. The aetiology of ankylosing spondylitis. Ann Rheum Dis 1949; 8: 143-8.

4 Gofton J P, Robinson H S, Trueman G E. Ankylosing spondylitis in a Canadian Indian population. Ann Rheum Dis 1966; 25: 525-7.

5 de Blécourt $\mathrm{J} \mathrm{J}$. Five hundred and thirty-three patients with ankylosing spondylitis, seen and followed in the period 19481971. Ann Rheum Dis 1973; 32: 383-5.

6 Gömör B, Gyodi E, Bacos L. Distribution of HLA-B27 and ankylosing spondylitis in the Hungarian population. $J$ Rheumatol 1977; suppl 3: 33-5.

7 Holst H, Iversen P F. On the incidence of spondylarthritis ankylopoeitica in a Norwegian county. Acta Med Scand 1952; 142: $333-8$.

8 Stoia V I, Rammeantu P, Stoicescu M, Dragomir H. Epidemiologisch und Familienuntersuchungen bei drei chronischen rheumatischen Erkrankungen. $Z$ Rheumatol 1969; 28: 201-7.

9 Van der Linden S. Spondylitis ankylosans (SA): Epidemiologisch untersuchung. $Z$ Rheumatol 1982; 41: 186.

10 Julkunen H. Rheumatoid spondylitis. Acta Rheumatol Scand 1962; suppl 4.

11 Bachmann A. Ein Betrag zur Spondylarthritis ankylopoetica. ROEFO 1930; 42: 500-9.

12 Calin A, Fries J F. Striking prevalence of ankylosing spondylitis in 'healthy' W27 positive males and females. A controlled study. N Engl J Med 1975; 293: 835-9.

13 Brewerton D A, Hart F D, Nicholls A, Caffrey M, James D C O, Sturrock R D. Ankylosing spondylitis and HL-A27. Lancet 1973; i: 904-7.

14 Schlosstein T, Terasaki P I, Bluestone R, Pearson C M. High association of an HL-A antigen, W27, with ankylosing spondylitis. $N$ Engl $J$ Med 1973; 288: 704-6.

15 Cohen L M, Mittal K K, Schmid F R, Rogers L F, Cohen K L. Increased risk for spondylitis stigmata in apparently healthy HL-AW27 men. Ann Intern Med 1976; 84: 1-7.

16 Christiansen F T, Hawkins B R, Dawkins R L, Owen E T, Potter R M. The prevalence of ankylosing spondylitis among B27 positive normal individuals - a reassessment. J Rheumatol 1979; 6: 713-8.

17 Chappel R, Muylle L, Mortier G, Peetermans M, Brusselaers
H. Risque de développer une spondylarthrite ankylosante chez des personnes 'en bonne santé' porteuses de l'antigène HLA B27 Acta Rheumatol Scand 1979; 3: 319-28.

18 Thelle D S, Førde O H, Try K, Lehmann E H. The Tromsø heart study. Methods and main results of the cross sectional study. Acta Med Scand 1976; 200: 107-18.

19 Thelle D S, Arnesen E, Førde O H. The Tromsø heart study. Does coffee raise serum cholesterol? $N$ Engl J Med 1983; 308: 1454-7.

20 Bennet P H, Wood P H N. In: Bennett P H, Wood P H N, eds. Population studies of the rheumatic diseases. Amsterdam: Excerpta Medica, 1966: 456.

21 Dale K. Radiographic grading of sacroiliitis in Bechterew's syndrome and allied disorders. Scand J Rheumatol 1980; suppl. 32: 92-7.

22 Gran J T, Smith-Mellby A, Husby G. The prevalence of HLA-B27 in northern Norway. Scand $J$ Rheumatol in press.

23 Macrae I F, Wright V. Measurement of back movements. Ann Rheum Dis 1969; 28: 584-91.

24 Hart F D, Strikland D, Cliffe D. Measurements of spinal mobility. Ann Rheum Dis 1974; 33: 136-9.

25 Moll J M H, Wright V. The pattern of chest and spinal mobility in ankylosing spondylitis. Rheumatol Rehabil 1973; 12: 115-34.

26 Gran J T, Husby G. Ankylosing spondylitis. A comparative study of patients found in an epidemiological survey, and those admitted to a department of rheumatology. $J$ Rheumatol in press.

27 Calin A, Kaye B, Sternberg M, Antell B, Chan M. The prevalence and nature of back pain in an industrial complex. A questionnaire and radiographic and HLA analysis. Spine 1980; 5: 201-5.

28 Macrae I F, Haslock D I, Wright V. Grading of films for sacro-iliitis in population studies. Ann Rheum Dis 1971; 30: 58-66.

29 Hollingworth P N, Cheah P S, Dawkins R L, Owen E T, Calin $A$, Wood $P$ H N. Observer variation in grading sacroiliac radiographs in HLA-B27 positive individuals. $J$ Rheumatol 1983; 10: 247-54.

30 Ryan L M, Carrera G F, Lightfoot R W, Hoffman R G, Kozin F. The radiographic diagnosis of sacroiliitis. Arthritis Rheum 1983; 26: $760-3$.

31 Kuberski T T, Morse M G, Rate R G, Bonnell M D, Garland Wood J, Bennet P H. A hospital-based survey of radiological sacroiliitis and HLA-B27 and Cw2 in Naajo and Hopi Indians. Hum Immunol 1981; 3: 77-83.

32 Dekkers H J N. Spondylarthritis ankylopoctica (spondylosis rhizomelique) combined with peripheral arthritis. Acta Med Scand 1943; 113: 506-26.

33 Daneo V, Migone N, Modena V, et al. Family studies and HLA typing in ankylosing spondylitis and sacroiliitis. $J$ Rheumatol 1977; suppl. 3: 5-10.

34 Møller E, Olhagen B. Studies on the major histocompatibility system in patients with ankylosing spondylitis. Tissue Antigens 1975; 6: 237-46.

35 Khan M A, Kushner I, Braun W E. Genetic heterogeneity in primary ankylosing spondylitis. $J$ Rheumatol $1980 ; 7$ : 383-6.

36 Thorel J B, Cavalier B, Bonneau J C, Simonin J C, Ropartz C. Deshayes $P$. Etude d'une population porteuse de l'antigene HLA B27 comparée a celle d'une population témoin non B27 a la recherche de la spondylarthrite ankylosante. Rev Rhum Mal Osteoartic 1978; 45: 275-82.

37 Hawkins B R, Dawkins R L, Christiansen F T, Zilko P J. Use of the B27 test in the diagnosis of ankylosing spondylitis: a statistical evaluation. Arthritis Rheum 1981; 24: 743-6.

38 Khan M A, Khan M K. Diagnostic value of HLA-B27 testing in ankylosing spondylitis and Reiter's disease. Ann Intern Med 1982; 96: 70-6. 